\title{
O POWOŁANIU NARODÓW DO CHRYSTUSA
}

Temat powozania wszystkicn narodów do królestwa Chrystusowego, dominująoy w źródzach objawienta, by $\mathbf{z z e r o k o ~ o p r a c o w y w a n y ~ w a s a c h ~}$ patrystycznych na sposób teologiczny. Hównlet na szeroka skale rob1z to ośrodek rzymsk1. Tutaj chciatem sie ograniozyd do jednego dziełka patrystycznego o tytule par excellence historiozoficznym:"De vocat1one omnium gentium 2 moloh poprzednich badar nad tym opusoulum zdaje s1e wyniká, te powstało ono na gruncie myśl1 1 plom ó́rodka rzymskiego w trzeoh kolejnyoh etapach 1 wersjach zarazem: ksiega I /rozdz. 1-25/ ok. r. 460, byé moze p16́ra św.Prospera z Akw1tani1, - rozwlazaniach paxtykularystycznych, dosyć pesymistycznych 1 rygorystycznych co do zasiegu lask1 chrześc1jańsk1ej, ks1ega II /rozdz, 2-29/, bl1sko r. 470, o rozwlazaniach bardziej uniwersalistycznych oraz ep1Iog stanowlacy Jakby k81ege III/rozdz. 30-37/ wraz z drobnym korektaml wiazacyml oble ks1egl redakcyjnie o duchu zdecydowante uniwersal1stycznym 1 godnym wielkośc1 ośrodka wizj1 Kościoła powszechnego. Całośd została zredagowana niewatpliwie po śmierci śm. Prospera 1 ém.Leona Wielkiego 1 zrobiz to któ trzec1, woparciu o 1oh p1ama, byó moze Hilary, za Leona diakon, a po nim papiez $/ 461-468 / 2$. Sam tytuz jest, Jak sie zdaje, wziety a p1sm sw.Leona, choc moze pochodzić z czasón o wiele póńniejszych, kiedy to jeszoze mocniej dojrzala mý́l, te spory pelaglaŕskie, a zwłaszcza semipelagianskie, dotycza nie tylko sposobu zbawienia jednostk1, alo takze całyoh narodón, m oparciu o nakaz misyjny: "dooete omnes gentes, baptizantes eas" Mt $28,18 /^{3}$. Ksiega I musiaka mié plerwotnie tytuz zblizony do Augustynowego: "De gratia et libero arbitrion.

1 Korzystan a najbardz1ej dostepnego wydania D.Mangeanta, PL 51, 647-722. Por. tez: P. de Letter, St.Prosper of Aquitaine, The Call of All Nations, London 1852.

2 Cz.Bartnik, L Universalisme de 1 histo1re du salut dans le "Do vocatione omnium gent1um", HHE 68/1973/731-758; Tenze, Autoretwo 1 struktura teologiozna "De vocatione omnium gentium" RTK 24/1977/ z.2, 41-62.

3 Por. De vooatione omnium gentium II 2, PL 51,687C. 


\section{Podstawowe teologumena}

Trzeba pamiętá, ze w dziezach teologicznych wszystkioh ozasón występuja pewne ogólne tezy, których sie bynajmniej nie dowodzi, lecz które okréslaja - jakby niewidzialnie - charakter wywodów teologicznych, mental ność teologa 1 , przynajmniej w pewnym stcpniu, sposób tematyzaoj1 św1adomośc1 teologloznej. Sa to tzw. teologumena. Teologumenon nie oznacza tu ogólnej oplnil teologón na temat jakiejé kwestil, lecz raczej to, co wermeneutyce teologicznej nazywa sie przedrozumientem teologioznym.

1. Jednym z wazniejszych teologumenów "De vooatione omnium gentium" jest mało utematyzowane przekonanie, te "laska Boza" /ks. I/ 1 "kaska chrześcijańska" /ks. II/ jest " Jakimś sensie widzialna w śrvecte doczesnyu, czyl 1 poznawalna w znaku Kościoła , w pewnego rodzaju skutkach /effectus gratiae/ ${ }^{5}$ oraz w calokształcie doswladczenia chrzesicijańskiego /experientia, experimentum ${ }^{6}$. W poznamalności tej główna role odgrywa zapewne objawiente, ale zawsze v reflekslo śwlata doczesnego 1 poznania takze naturalnego. Obejmuje co najmniej faktyczność zask1: "ze" zaska 1 "ato tutaj" zaska. Nówiąo bardziej praktycznie, ekonomia kaski Bozej wciela się tak gięboko w historif doczesna, te ohoc nie poznaje ale tajemnioy 1stoty łask1 an1 racj1 1 przyczyn dzlałań Bozyoh, to jednak w pewien sposób dostrzega sig, kto danym czasie 1 stanie jest na drodze do zbawienia, a kto nie, Jak 1 naród jest ohrześcijański 1 powołany do raski, a jaki nie, gdzie dzieje sie ohrześcijaństwo/sakrament, wlara, słowo, moralnośc/, a gdzie trwa pogaństwo, niew1ara, zło moralne. W naszym dziełku zdaje sie tkwić przekonanie, te taka widzialnó́ó staje sie z czasem coraz wyraźniejsza , a nawet ze caze chrześc1jaństwo wyjaśnia sie człowiekowl coraz bardziej takze z pozyojl historycznych przokształoeń 1 następujacych w ozasie 1 przestrzent

4 Taunze, I, 12,664C; II, 14,700A; II, 23,709D.

$5 \quad I, 25,686 \mathrm{~B} ; \mathrm{I}, 14,666 \mathrm{C} ; \mathrm{II}, 16,704 \mathrm{~A} ; \mathrm{II}, 33,717 \mathrm{C}$.

$6 I I, 10,695 A ; I I, 15,701 \mathrm{~A} ;$ II $, 34,710 \mathrm{~B}$.

$7 \mathrm{I}, 23,678 \mathrm{D} ; \mathrm{II}, 18,7063 \mathrm{C} ; \mathrm{II}, 23,710 \mathrm{~A} ; \mathrm{II}, 31,716 \mathrm{C}$. 
przemian 8 . Po prostu zivieńcza siz ona waturze bytu Kościoła, który - mimo gwej tajemnicy głębi - jest widzialny, dotykalny, przeżywalny, zwizzany nierozerwalnie z konkretnym zyclem poszczególnych ludz1 i narodów. Przykładem tego jest eklezjalizujace slę Imperium Homanum. W kaźdym razie zakłada sie, ze możliwe jest samookreslanie sle chrześcijanina, a takze narodu 1 całego Kościola na sposób realny 1 widzialny.

2. Innym waznym teologumenem jest przekonanie, ze świat wieczny yazczy się z niezintennośc1a, jednością, róinościa 1 harmonia słusznośc1, natomiast światem stworzonym rządzi zmienność, mnogośc, nierówność 1 najrozmaitsze zróznicowania: divorsitates, inaequalitates, varietates, differentiae, dissimilitudines, discretiones. Dlatego 1 łaske, będąca z istoty zasada jedności, o lle wciela się w ten śwlat, wtedy rozszczep 1 a sie na różnorodność 1 mnogość form. Oddaje to dobrze zdanie: "multiwodae vocationis varietas ad unam gratiam pertinens ${ }^{9}$. Racja takiej rózności skutków łaski wcielonej nie jëst znana, ale dla ówczesnego teologa rózność taka jest spocyficznym "dogmatem": "Jezeli bowiem nie wiem, dlaczego jeden stworzony został Jako Grek, a drugi jako barbarzyrica, jeden rodzi się wśród bogactw, a inny w nledostatku; dlaczego jednego wywyzsza zdrowie 1 piękno smukłego ciała, a drugiego zniekształca brzydota 1 niedołezznośc zmarniałych członków; dlaczego jeden, wydany na świat przez rodzicóv katolichich, karmiony jest prawdą kołysce, a drugi będac potomstwem heretyków już z mlekiem matki ssie zarazę błędu; Jezel1 wreszcie nie moge rozsadzic tysiąca 1nnych róznic w sprawnościach ciał, przymiotach ducha, warunkach życia różnych czasów, kulturze regionów - to nie znaczy bynajinniej, iź nie wiem, ze Bóg wszystkie te rzeczy stwarza 1 urządza. Doprawdy Bóg, a nie los, stworzył ciała 1 dusze poszczególnych ludzi tak, że oprócz różnorodnośc1 dązeń 1 postepowaí, wynikajazcych z wol1 kazdego, zostały zróżnicowane na niezl1ozone 1 jak najdalej odbiegajace 98 siebie sposoby
same poczatki sytuacj1 zyciowych"

8 II, 34,719B: "… quidquid in universitate rerum per saecula prasfinita evolvitur, ac multimodis varietatibus explioatur". Por. II, $11,695 \mathrm{D}-696 \mathrm{AB}$.

$9 \quad I, 17,670 B$.

$10 \mathrm{I}, 14,666 \mathrm{D}-667 \mathrm{~A}$. Por. I, 13,666A; I, 16,669A; I, 24,679A. 
Słowem, łaska chrześcijańska jest rozpatrywana na tle rzeczywistoso1 pleskoriczente zróznicoranej. Nieporównywalne jest w swych konkretnych kształtach zycie jednostek 1 narodóm. Najrozmaltsze sa rodzaje darów, a każdy rodzaj ma jeszcze rózne stopnie, 1lośc1 1 etapy rozwojowe. Istnieja narody powołane 1 - na sposób widoczny - nie porozane, wielkie 1 małe, znane 1 nie znane. Zadziwiajace jest zrózntoorante religljne: poganie, Izrael, ohrześcijanie, a takze prawowiern1, odszczepleńcy, heretycy, święc1, przeoletni, wielcy grzesznicy. Ekonomia zbawienia dzieli sie na epoki, kregi oraz szozególne momenty czasu 1 punkty przestrzent. Dlaczego Duch Swiety powstrzymał ś.Pawła przed głoszentem Ewangel11 nlektórym naxodom Azj1? Czym wytłumaczyó tak różne motywy woll ludzkiej 1 rózne sposoby percepcj1 z jeJ strony Woll Bozej, lqcanie z odmiennym losem niemowlat, które przeclez w ogóle nie wyrazaja swojej wol1? 11

W kazdym razie rzoczywistość ogladana ze strony teologil Jaw1 s1e nam wszystkim jako perna jednoś, ale 1 zarazem nieskończona róznorodność, mnogość 1 nie dająca sie sprowadzić do wspólnej zasady nleokreśloność. Jako podstarowe zasady tłumaczenla tego stanu rzeczy beqda tu słuzyły kategorie: Woll Bozej, woll ozłowieka, woll narodu 1 mistorium wiary w ukryty sens.

3. Istotny jest tez teologumenon pernt, odzledziozony jeszcze z myślonia staromezopotamskiego. Effectus gratiae 1 varietas humana sa poddane pewnej zasadzie ruchu "ku Pełni". Jest to ruch od poczatku do jaklegoś, określonego 1 pozzdanogo końca, od elementór eragmentarycznych ku integralnej całośc1, od zaledwie prawdopodobnych poznań do pełnego sensu, od róźnyoh względnośo1 ku czemuś absolutnemu, od niedoskonałośc1 ku doskonałośc1, od ułomnej woll ludzklej 1 ludzkich planów ku Woli Bozej 1 centrum Ekonomil Bozej. Kategoria "pełni" zastępjo dzisiejszy teologumenon ruchu, historil, rozwoju, ewolucjl ku punktowi Omega.

W omawianych tu ramach tematycznych pełnia powozanta zaczyna s1e od 1dei, ze Bóg ustanowił llośd narodów zieai stosornie do 11ozby anlołów, każdy anioł wiedzle swój naród - nawiązaniu do narodu wybranego - do Niebieskiej Jerozolimy przez tajemnicze drogi his11 II, 3, 688-689; II,6,691-692; II, 9,694AB; II, 11,695-696; II, 14,698- 
tor 11: "Gdy Najwyższy rozgraniczał narody, na sposób rozstaniania gynóv Adamónch, wtedy narodom wytyczyz granice według liczby anioIón Bożych, przy czym szczególnym dziedzictwem Pana zostar Jego Lud Jakubowy" /Pwt 32,8 Vetus Latina/12. Poglad, ze narody z1em1 "wypeiniaja" " jakiś sposób liczbę aniolów clagnie sie odtą az po ostatnie ksiegl Nowego Testamentu. Sw.Pawel dostrzega antysymetrie zbawcza " tym eonsie, te z kolel Izrael, który byk ludem wybranym, nawróol sie " całośc1, "gdy do Koścloza wejuzie peznla pogan" $\mathrm{Rz}$ 11,25-26/. peinia narodóm/gentium plentiudo/, powszechnoś́ narodón/universitas gentiun/ ${ }^{13}$. Według Apokalipsy koniec śriata nastap1 doplero wtedy; gdy dopezni sie Jakas tajemnicza liczba na ziem1 ludzi 1 narodóws "... az pełna l1czbe oslagna takze $1 \mathrm{ch}$ mspólskudzy oraz brac1a, którzy, jak onl, maja oddać zyclen/Ap 6,11/.

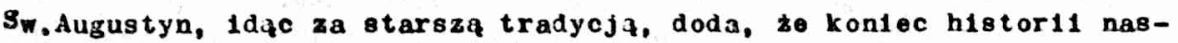
tapi wtedy, gdy liczba zyjacych na śwecie ludzi zrónna siz z lloścla aniołó odpadzych.

F kazdym razie peznia narodón jest jakiłs kategoria 1 zarazem determinanta historyezna, okreslaj zca etapy ekonoril Bozej: na początku z pierwszych ludzi rozwinça sie pełnia narodón, poter po potople odrodziza sie nora pernia a arki Noego, znowu ulesla rozbiciu w okresie wiezy Babel,ale zaczeza sie ksztaktowac w Narodzie fiybranym 1, wreszole, tworzy sie eschatyczna pelnia Kościele katolickin ${ }^{14}$ - Wodzug éw.Pawza Jezus Chrystus nie jest nikin Innym, jak speznicielem narodów: wim jest ucieléńlona Fola Boga "dla dokonania pełni czasó, aby wsystko na nowo zjednoczyc - Chrystusie jako Gzow1ew/Br 1,9-10/. Ten sposób Chrystus staje s1e ostatecznym typem 1 zarazem speznienlem bytu, zycla, histaril, liczby 1 sensu wsaystikioh narodów ${ }^{15}$. Pojecie "pełni wyszo tak dalece na czoło innych pojeć teolog1canycin, ze stało sie zasada nisteryjnq, dalek4 od aýlonia liczborego 1 llosclowego, sprowadzang nieraz - nawet

$12 \quad I, 5,651 C$.

$13 \mathrm{I}, 13,665 \mathrm{~B}-666 \mathrm{AB} ; \mathrm{I}, 21,67 \mathrm{~A} ; \mathrm{II}, 29,715 \mathrm{~A}$.

$14 I X, 14,699 \mathrm{ABC}$.

$15 \quad I, 9,661 \mathrm{AC} ; I, 11,663 C_{;} I, 13,666 \mathrm{~B} ; I, 17,670 \mathrm{~B} ; I, 23,6765 ; I Y, 4$, $691 \mathrm{~A}$; II, 29,715A. 
z aspektam1 nadużyoia, jak w ks. I - do symbolów, które bynajmniej nie wyrazaly ant pełni, ant prawdziwej powszechnośc1, Jak: speolalis universitas, pars pro toto, substitutio unius pro universis, de toto mundo totus mundus /particulariter/ assumptus, pro omni gente una gens ${ }^{16}$.

\section{Misterium powozanta}

Wszyetk1e częśc1 "De vocatione omnitum gentium" unikaja predestynacj 1 rygorystycznym ujęc1u św.Augustyna, a więc nie tylko nie uzywaja terminu "praedestinatio", ale nawet unikaja słynnego tekstu Parłorrego: "Albowlem tych, których od wieków poznał, tyoh tez przeznazyz na to, by się stali na wzór obrazu Jego Syna. Tyoh zaś, których przeznaczył, tych tez powozaz, a któryoh powozaz tych tez usprawledliwiz, a których usprawledliwiz - tych tez obdarzyl chwałą" /Rz 8,29-30/. Jest jedynle ogólna mý́l, te Bóg "v Chryotusie wybrał nas przed załozeniem świata, abyśmy byl1 b́więc1; z miłośl przeznaczył nas dla sieble Jako przybranych synóm przez Jezusa Chrystusa" /EP $1,4-5 / 17$. Na ezczycio tego przygotowania do ekonom11 Bozej atol powolanie/vocatio/, które jednak optera sie na poprzednich etapach 1 wiqze $818 \mathrm{z}$ nimi:

1. Bóg na mocy wiedzy uprzedniej/praecognitio divina/ określa z góry wazelkie tstoty 1 loh dzieje bez względu na ozas 1 ozynnik ludzkiej wolności; odnosi s1ę to takze do kazdego narodu ${ }^{18}$;

2. Potem następuje płynący z Wol1 Bozej wybór kazdej jednostk1 1 każdego narodu do szozególnej rol1 wamach ekonomil Bozej: "electio omnium gentium"19;

3. Po wyborze ma miejece adopoja, czyli szozególne zwiazanie ludzi I narodów z rzeczywistościa Syna Bozego, a wiǫo przyjęcle ich za synów: "omnium gentium adopt10"20;

$16 I, 9,661 \mathrm{ABC} ; \mathrm{I}, 10,661-663 ; \mathrm{II}, 2,688 \mathrm{BC}$.

17 II, 33, $718 \mathrm{BC}$.

$18 \mathrm{II}, 34,719 \mathrm{ABC}$.

$19 I, 21,674 \mathrm{~B}$.

20. $I, 13,666 \mathrm{~B}$ 。 
4. I wreszcie ma miejece powołanie, czyll szczególna realizaoja historyczna narodu chrześcijańskiego we wszystkich wymlarach: "vocatio omnium gentium" 21 .

Vocatio oznacza nie tylko dzlałanie Boze na czele z apelem do ozłowieka 1 narodu, lecz takze pezna, konkretna 1 dzlejotwórcza odpowiedz ze strony ludzkiej. Dlatego uwaza $81 \theta$, ze los narodu kształtuje sie "zaleznoścl od stosunku do tego powołania. Archetypem jest tu powozanle narodu 1zraelskiego. Jakkolwiek czę́́ć narodu sprzentewierzyła sie temu indywidual nemu 1 zbiorowemu powołaniu, to jednak pozostaje on na zarsze pewnym "sakramentem" dla narodów 1 prototypem powołania narodór. Temat tego porołanla obejmuje całe dzjeje ludzk1e. "De vocatione omnlum gentium" narizzuje tu do zdania sw.Pawła, ze "w przeszłych pokolentach Bóg pozwol1z wszystkim narodom chodzió swoiml drogami" /Dz 14,16/, a nawet ze "Pan rozproszył narody, Jak synów Adama w ozasach wiezy Babel" ${ }^{22}$, uzyøająo powszechnoś powołania wszystk 1 ch narodó za przedwczesne 1 pychodzace na szkode samym tym narodom. Sw.Prosper z Akwitanil widzlał tę przeszłość narodów całkowicie negatymie jako czasy fałszywej reílgii, nieprawośc1, odrzucenla od Boga $1^{\circ}$ dopuszczenia przez Boga panowania grzechu w Innych narodach poza Izraelem ${ }^{23}$. Autor traktatu "De vocatione omnium gent1um" widz1 to bardz1ej optymistyczn1e. Juz w księdze I naucza, ze choó Bóg podzlelił śwlat na dwie części: na naród Pana 1 narody wasnej rol1, to jednak 1 dla tych narodów by to czas Opatrznośc1 Bozej, obdarowywania ludów rszelkiml daraml natury, moz11wośct poznanta Boga na sposób 1ndywidualny 1 społeczny w ramach rel1g11, a także otrzymywania jakiejó laski Bozej ${ }^{24}$.

W księdze II widzi najdawniejsze czasy jeszcze bardziej optymistycznie. Narody te zyły "secundum propriam voluntatem", ale Pan dawał im wezystkie dary swej dobrool, ukazywat niewystowione piekno

21 II, 18,706BC; Por. II,33,718C; "Omnes enim qui in regnum De1 de ouiusilbet temporis vocatione venturi sunt, in 1sta, quae cuncta praecessit, adoptione signati sunt"; II, 33,717-719.

$22 I, 5,651 C$.

23 Por. Contra collatorem X,3,PL 51,241B; Eplstola ad Rueinum XI, 12, PL 51,84AB; Responsiones ad capitula Gallorum $I, 8, P L 51,162 B$.

$24 I, 5,651-652 ; I, 13,666 \mathrm{AB} ; I, 21,674 \mathrm{~B}$. 
́́wlata $i$ majestat stwóroy, dzlałał oczywiste cuda, wszozepiz wature 1 serca ludzkie tablico odwieoznogo prawa, ozuwal nad kaztaztowaniem sumienta moral nośl, wylewax gzczodrze na wszystkioh swoje miłosierdzie, pozwoliz utworzyó elementy prawdziwego kultu /cultus/, a nawet wylał na wszystkie narody zaske nadprzyrodzona, płynąca z Jego Narodzenta 1 Zmartwychwetania, napezniajac cała ziem1e Duchem Sw1etym ${ }^{25}$. Była to po prostu ta oama zaska, co ozasach powołanla chrześoljańskiego, Jakkolwlek nie była ona tak jasno ukazana, tak szeroko rozlana, ani tak "1nstytuojonalnie" zorgandzowana.

Przykładem nieustająoej, wszechstronnej troskl Pana o narody byly wydarzenia potopu 1 wiezy Babel. Byzo to odpowiednie przygotowywanie prawdziwego 1 peznego powozanla wazystkich narodó: "praeparatio nationum ad populum De1". W aroe Noego byzo "seminarium wszystkich narodów". I były tam jednoozénile dary Boze, zbawiente, odrodzente przez drzewo 1 wode, zaczatek kultu Boga, mzrastaka wielokształtna laskà Boza /multiform1s gratia/, prawda 1 wolnośd, była dobra wola ludzka 1 pierwotne sakramenty. Tak wię znowu nszystkio narody były przygotowywane do powozania do Kahal Jahwo. Alo z czasem zło zdobyło przewage nad dobrem 1 rozwój narodów zostaz - przez zła wole - obróoony przeolwko Ich Bozemu powołaniu. Wtedy dopuśolz Pan, zeby jeden Język ówozeanych narodów rozb1z 18 na 72 Jezyk1, zn1kła komuntkacja między narodami, zglnęła zgoda 1 wapółpraoa, powstały "złe kớcloły" /mala congregat1o/ 1 nastap1ło rozproszenie po całej ziemi bez zachowania wajemnyoh wiezi międzynarodowyoh. Trzeba było znowu tworzyó jak1é́ nowe "seminarium narodón", czyniz to Abraham, 0jc100 wiary 1 0jc10o narodón duchowych św1ata. W osobie Abrahama dokonało B1e szczególne powołante narodu wybranego, majaoego być z kolel typem narodu chrześc1jańskiego, złozonego juz ze wszystkioh narodów na wiek1 ${ }^{26}$. Wszakze do dzí́ 1stnieja ludy /aliquae nationes/. które sa na owym najdawniejazym. statusio powozania, kiedy to Pan dozwalax im ohodzic swoimi drogami ${ }^{27}$. Historyoz-

25 II, 4, 689-691; Por. II, 5, 691B; II, 14,700AB.

26 II, 14,698-700; II, 31,716C.

$27 \mathrm{II}, 17,704 \mathrm{BC}$. 
ne Pazy powołania narodów nie sa odcinkami jednej linil, lecz maJa róże czasy przeznaczenla, mieszaja sie ze soba 1 nieraz czas powołania jednego narodu wspókegzystuje z czasem niepowołanta jeszcze druglogo narodu.

Od strony merytorycznej powozanie człomieka 1 narodu okreslone jest przez tró́c1 chrześcijanstwa. Mozna mówió o trzech zakresach powotania: o powołantu wiecte, w dziejach zbawienia na zlemi oraz o powolaniu wiecznym. "De vocatione omnlum gentium" posiada jedynie aluzjo co do powozania czysto doczesnegos jest nim os1agnięle doskonałośc1, szczéscla, kultury ducha 1 pomoc usensownianiu zycla innych narodów. Wyraźniej jest rozwijane powołanie wleozne: do zyola wieoznego - "vocandi ad vitam aeternam popu$11^{28}$, do Królestwa Bozego 29 do zbawienla w oensie P1nalnym omnlum nationum sal us "30, które jest oddawane takze innym1 terminami: Iustificat10, redemptio, regeneratio, reformatio, nova creatura, recono1l1at10, plenttudo. Najwyrazniej jednak jest omawiane porołanie historiozbawcze. Personalnie móniac jest to powołanie do Chrystusa 1 Jego królestwas "omnes gentes in regnum Christ1 vocantur" ${ }^{31}$. Od strony egzystencjalnej jest to powołanie do raski chrześcijańskiej - "ad gratiam chrigtianamn32. Przy tym pojeciu laski mieszcza się tez treśc1 bardziej szozegółowe, a mianow1o1e: świetó́d, dziedziotwo zyola Chrystusa, nauka niebianska, mikosierdzie Boze, Ewangelia, modlitwa, uczestnictwo wisteriach zbawczyoh Chrystusa ${ }^{33}$. Najbardzlej właśoliym przeciwstawientem $\$$ stosunku do sytuacjl chodzenia "swolmi drogami" oraz "rozproszenla narodón" jest ich powolante do jednoscl duchowej Kosclele powszechnym: "nationes vooandae ad unitatem Corporis Christin ${ }^{34}$.

Ostatnie sformulowante nalezy do znanes "theologia romanita-

$28 I I, 15,700 C$.

$29 I, 12,665 A$.

$30 \mathrm{I}, 20,672 \mathrm{D}$.

31 II, 18,706C. Por. II, 16, 702-704; II, 18,704C.

32 II $, 14,698-700$; II, 16, 704A.

$33 I, 9,660 C ; I, 14,667 \mathrm{~A} ; \mathrm{I}, 17,669 \mathrm{C} ; \mathrm{I}, 20,672 \mathrm{D}$; II, 2,688C; II, 10 , 695ABC; II, $17,704 \mathrm{~B}$; II, 36,720-723.

34 II, 16,704A, Por. I, 12, 664B; II, 14,699ABC. 
t1s", czyl1 rozwijajacej s1e w ośrodku rzymskim ide1 szczególnego posłannictwa Imperiun Romanum oraz Koścloła Rzymu. W wersjl autora II ksiegl "De vocatione omnium gentium" naczelnym powołaniem 1mperium rzymskiego było przygotowante dla Koścloła chrzéscijańskiego jakiejé doczesnej powszechnośc1 1 zarazem jednośc1:

"Ad cuius rei effectum credimus providentia De1 Romani regni latitudinem praeparatam: ut nationes vocandae ad unitatem 35 Autor uwaza, ze laska chrześcijańska siega znacznie dalej nłz Rzym, obejnujac więcej narodów, ale powozaniem historycznym imperium było przygotowanie dla tej kaski wielkiej rozległośol terytorialnej 1 społecznej, struktury jedności ludzkiej o oharakterze wiezi miedzynarodowej, a wreszole Instytucjl jednej wadzy naczelnej, która stała sie opatrznościowa pomooa dla wykonywanla wadzy prymatu kośc1elnego: apostol101 sacerdot11 prinoipatus. Stąd trzeba wnosić, ze powołantem kazdego narodu jest wnoszenie wkładu do jednośc1 ludzklej, zarówno wensie doczesnym, Jak 1 rellgijnym, gdyz Kośołóx jest mistycznym anły daży całym swoim źyolem do jednośl rodziny narodów oałego d́wlata. Powstaje jednak problem, ozy z "teologil rzymskosol" nie wynika, ze w miejsce Imperium Romanum w przygzłości nad śriatem będzle panował Koścí́z chrześcijariski z papiezem na czele? Jakkolwiek wówczas nie rozrózntano jasno spozeczności państwowej od spozecznośct eklezjalnej, to jednak wydajesie, te w "theologia romanitatis" nie chodzi o sensy doczesne. Powołanie narodów sprowadza się nie do utworzenia nowego imperium chrześcijańskiego, lecz misterium Kościoła jako najwyżzego etapu ekonomil Bozej 1 jako szozytowej postac1 antropogenezy spożecznej. Przy tym 1 mperia 1 królestwa bę-

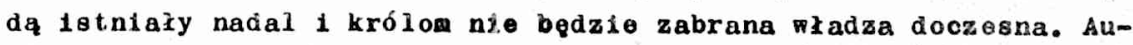
tor mów1 oharakteryetyoznie o "olele" Chrystusa 1 o "zasce chrzeác1jańskiej", rozlewającej sle na wazystkie narody śwlata. oczywícle, "Imperium Romanum" pozostaje pewnym wzorem dla vięi miedzynaxodowej zarówno doczesnej, Jak 1 eklezjalnej: Jest ono bowiem tworem, stóry

35 II, 16,704A. Por. Leo Magnus, Sermo 82,2, CC 138A, 510-511, w.4054 .

$36 \mathrm{II}, 14,699 \mathrm{ABC}$. 
nazywano chętnie za Izajaszem /9,2/ w tzumaczeniu Vetus Latina: "gentium populus" /naród ludów, lud narodów lub nawet naród narodów/37. Podobnie w nazwie "populus chrletianus"38 byłoby Jakieś nawiazanie do 1del narodu kolektywnego, oczywície, w sensie misterium, przypominajacego "populus messianjcus". W ośrodku papieskim nie dominowały pojęia polityczne, looz kategoria misterium: Ciaza Chrystusa, Królestwa Chrystusa, Narodu Lask1 Chrześc1jaĺskioj. W "narodz1o chrzé́c1jańskim" chodzi o jaká́ duchowa l misteryjna "spełnię narodów" /A.Cieszkowsk1/, w której kazdy naród historyczny otxzymuje waściwa soble role 1 zaden nie jest zepciniety na margines dzlejów powszechnyoh: "nulla nationum facta discretio est" ${ }^{39}$. Sredniowieozne 1dee: Imperium Karola Wlelklego, cesarstwo rzymskie narodu niomiecklego oraz "res publica christiana" mogxy nawlizywac do "theologia romanitatis" ośrodka papieslsiego, alo nie sa bynajmniej jej prosta kontynuacja ani nawet konsekwencja.

\section{Zakrosy powołania}

Jakkolwiek dziełko "De vocatione omnlum gentium" dzieli spozeczność ludzką, zgodnle z treściaml chrześcłjańskiml, na chrześciJańska 1 niechrześc1jańską, krocząoa droga zbawienia 1 schodząca na droge. potepienia, na rzymska 1 barbarzyńska, to jednak jego naczelnym dzzeniom jest przedstawienie uniwersalizmu powolanti dla ludzi 1 narodów "dobryoh". Dlatego juz milkna w nim echa dawnej tradyoj1 semantycznej, gdzie gens lub natio oznaczało nie-zydów lub pogan w ogóle. W zasadzle gens, gentes, nat1o, populus, populi, plebs posladaja te sama godnośó, co Izrael 1 Rzym. Jedynie terminy gens

1 natıo są nieco bliżej sonsu antropologicznego, plebs natoriast 1 populus nieraz bardzlej oznaozaja "ludnośc" lub "spozeczeństwo". Jest to plerwszy znak uniwersalizmu chrześcijańskiego w wizji powozanta narodów.

Untwersalizm nie utoźsamia sle z negaoja omawianoj różorodnośct ant nieistnientem etapón historyoznyoh. W omawlanym przez nas

37 Por. $I, 15,668 \mathrm{~B}$; II, 15, 702A.

38 Np. I, $8,657 \mathrm{~B}$.

39 II, 2, 687D. 
traítaole nie ma śladów rozporszeohnlonego na Zachodzie dzieienta historil powgzechnej na 6 epok stosownie do 6 dni stworzenta, ant wersji ojców Kapadockich: epok1 doczesnej 1 wiocenej, ale raczej wystepuje podziaz oparty na ldel odkupienia przez Chryetusa, a nięo zblizony do Prosperowego: ante legem, oub lege 1 oub gratias

1. epolsa prawa stworzenia, ozyli natury /aeternae leglo tabulae, elementorum fanulatus/;

2. epoka prawa /sub lege, tempora legis/;

3. epoka ozasów esohatyoznyoh po przyjéc1u na ślat Chrystusa /tempus redemptoris, novissimum tompus/ ${ }^{40}$.

oozywície, nie sa to epok1 równorzęune soble, gdyz dwie plerwgze schodza 918 ostateoznie if jeden okreo przedohrześo1jarisk / eterita saecula, praeterita aetas/, w Jakies "przediem" /ante/, a ostatnia oznacza okres chrzeboljańsk1/nostra saocula, tempora gratiae ohristianae/ lub po prostu "terazniejszó́d" /nuno/1. Epoka trzecia jest juz ostatnia. Tak wierzyzo oake chrzeseljanstwo. Zdaje s1ę, te ostatnia rodakoja ujęza trójpodział niemal w sensio nauk owy m:

1. wlok1 plerwezo, zapowne od etworzenla do ozasu przymierza;

2. wieks średnie, najprawdopodobniej od Abrahama do Chrystusa;

3. wieki najnowszo/novissima saeoula/, zal naugurowane przez Chrystusa 42 .

Redalstor przezywaz znane wahania, oo uznat za raoje zakonozen1a epok1. Wybrat wersjo zachodnia, rzymska, te Jakkolwiok Pan historil dziaza tylko na podstawio ewojej, niozym nie skrepowanej woll, to jednak za motyw do zakonozenta epokt pierwszej 1 druglej, czyl1 przed potopem 1 przyjóotem Chxystusa, walal głęoki upadek ludzkosol

40 II, 4,690-691; II, 9,694B; II, 10,695B; II, 14,700A; II, 15, 700C; II, 17, 704C; II, 18,706C; II, 25,710D; II, 31,716B.

$41 \mathrm{I}, 11,663 \mathrm{C}$; II, 3,689B; II,4,689C; II, 9,6940; II, 15,700C; II, 25, T11A; II, 31, T16B; II, 34, T18C.

42 II, 25,710D: "SIve 1gitur novissima oontenplemur saeoula, seu prima, seu media, rationabiliter creditur omnes homines aalvos fleri Deum velle, semper volulsse". 
pod względem religl jnym, duchowym 1 moralnym ${ }^{43}$. Wyjattis 1 em będa chyba czasy ostateczno ohrześcijan, kiedy to nastapi roziswit Kościoła, czas duchowego dorobku narodów chrześc1jańsk1ch 1 okres zntw b́w1ata. F dziele jest bowiein pewna tendencja przyjmowania umiarkowanego rozwoju ozłowleka, o 110 taka "ewolucja" będzie przypisywana "dobroc1 Stwóroy" ${ }^{44}$. Ostateoznie autor dalek1 jest od pesynizinu. Stosuje on dialektylse Pawzowa: "Gdz1e jednak wzmógz s1e grzech, tala jeszcze obficiej rozlała 818 tagka" $/ \mathrm{Rz} 5,20 /$. Tak w1̨̨о im głobszy bywa upadek narodu, wieksza bezradnośd ludzka, dotkliwsze klęski, tym bardziej wzmaga s1e wopantałomyślnośc zask1, przybywa pomocy Buzej, objawia sie nlezwykzośd ekonomil Bożej. "Prawo" to umaonia wiare w powszechno 1 niezwykłe powołanie narodów w kaźdym czasie, choó po ludzku tego nio widac ${ }^{45}$. Przede wszystkim Boza ekonomia narodów jest wiekszej ozére1 zakryta.

Czy 1 w Jakim sensie zbairienie obejmujo wszystkie narody wszystcioh epok? Pytanie to nurtowało chrześcijan od poczatku. Ksigga I "De vocationo omnium gentium" daje odpowiedź dosyó pesyuistyczna. Opieraja sie głównte na Pawłowym tekśo1e: "Bóg zywy jest zbawca mszysticion ludzi, ale najbardzlej wierzacych" /1 Tm 4,10/, przyjmuje, ze epok1 przedchrześc1jańskie miaky raczej dary samej natury, zbaw16 s1e mogly tylko wybrane jednostk1, a wige faktycznie do zbawienla Chrystusowego sa powozane tylko narody chrzéscijańskie: popu11 ohristiant. Ksiega II /wraz z epllogiem/ natomiast oplera sie zasadniozo na przeolwstawnym nlemal tekśc1e: "Bóg ma wolg, zeby zbaw111 s 1 pezysoy ludzie 1 dogzli do przyjęola prandy"/1 Ta 2,4 Vetus Lat Ina/, a w180 nio ma tu ograniczonia laski nadprzyrodzonej do garstk1 tylko wybranyoh. Nie tylko Opatrznośc naturalna, ale 1 ekonomia zbawienta rozolaga 1 na cała ludzkós jako jedna 1 ta sama kaska chrzé́oljariska ${ }^{46}$. Od Abla 1stniaz prawdziwy lud Bozy, a w18o Koś-

43 I,6,652BCD; I, 8,656A; II,4,691A; II, 10,695C; II, 13,697C; II, 15, 700-702.

44 II, 11, 695D-696A; II, 1B,700CD.

45 II, 3, 689AB; II, 10,695BC; II, 15,700C; II, 17,704C; II, 18,705A; II, $19,706 \mathrm{C}$.

46 II, 4, 689C-690ABC; II, 9,6940 . 
c16ł Chrystusa: populus spiritualis, populus De1, Corpus Christi 47.

Niemniej pozostaje clagle problem zakresu faktycznego powołania. Odporiedz ldzie w tym kierunku, ze poivołanie narodór przed Chrystuser miało paktycznie wężzy zakres 1 było bardziej tajemnicze: "parcior ante atque ocoultior fuit"48. Realizaoja ta poszerzyza sie 1 uvidoczniła znacznie w opoce prawa ${ }^{49}$. Zreszta do dziś sq - 1 będa jeszcze długo - narody, do których kaska chrześcijańska nie dotarła:

"Być moze, ze jak onglé perwne narody nie zostały adoptowane do wspólnoty synów Bożych, tak równiez teraz na najdalszych krańcach świata znajduja sie jakiés narody, którym łaska Zbawiciela jeszcze nie zabłysla. Nie watpimy jednak, ze zakrytym wyroklem Bozyin 1 dla nich został wyznaczony czas powołania, kledy $y^{3}$ yysza 1 przyjma Ewangelie, której dotychczas nio usłyszel1" 50 .

Zaraz nawet następuje zapewntente, ze w owych czasach laska chrześo1jańska 1 Ewange 11 a obj ̨ła juz dosłownte wszystkie narody świata ${ }^{51}$. Prawdopodobnie chodz1 tu o powszechnośc w sensie moralnym, nie matematycznym, jednakże Intencja uniwersalnośc1 jest jasna.

U autora traktata "De vocatione omnium gentium" dostrzega se usilną tendencję wyjácia poza oblegowe wówczas pojęcia nie w pełni uniwersalistyczne. Ale krokt w tym kierunku sa stawlano bardzo ostroźnto. Raozej więc tylko potrqcana jost myśl, żo dostępują łask wienta wszystkie narody poza chrzéscijaństwem, lecz dzieje sie to w Jakí́ sposób zakryty przed naszymd oczyma, mozna powiedzié, "niewidzialnie": diversa mensura, occulte, per occultos modos, non manifeste, absconditum mysterium, misericorditer, spiritu gratiae, populus spiritual1s ${ }^{52}$. Kryje sie w tym mýs, ze zbawienie dokonuje s1e takize poza widzlalnymi znakan1 Kościoła, poza "ridzialną" łaska,

47 II, 10,695BC; II, 13,697CD; II, 15,700B. Podobnie Leon W1elk1.

$48 \mathrm{II}, 5,691 \mathrm{~B} ;$ II $, 14,700 \mathrm{AB}$; II, 17,704B. Moze tu zachodzí naw 1 azanie do Prosperowej polemiki z Kasjane⿰氵, według którego Chrystus tylko dla częśl byl Zbawoa/Salvator/, a dla reszty - Przyjmujacym /Susceptor/. Por. Contra collatorem XVIII, 2, PL 51, 263B."

49 II, 4,691A; II, 5,691B; II, 9,694B.

50 II, 17,704B.

51 II, 16,704A; II, 19,706C; II, 29,715AB; II, 33,717 BC.

$52 \mathrm{II}, 4,691 \mathrm{~A} ; \mathrm{II}, 4,690 \mathrm{BC}-691 \mathrm{~A} ; \mathrm{II}, 5,691 \mathrm{~B} ; \mathrm{II}, 11,695 \mathrm{C}$; II, 14,700A; II, 18, T04BC; II, 26,711C; II, 29,715C; II, 31,716D. 
która Jednak Jest 1 była zawaze laska Chrystusa. Tylko na tej zasadzie "nio nie zostaxo nie objete obecnościa 1 moca zbawienians. Leby rozwlazac antynomię: sprawledliwośc1 Boga wobec kazdego narodu oraz szczególnego obdarowanta łaska zbawienia tylko niektórych, poczyniono wówozas na Zachodzio rozrózniente między laska ogólna /gratia generalis/ 1 laska specjalna /gratia speolalis/. Zabieg ten byz metodologicznie niepoprawny, bo laska ogólna pokrywaza sié z dobrodzlejstwami natury bez zbaisienia, a doplero kaska speojalna miałaby dawać faktyczne zbarionio. Nasz autior analogicznio rozróżnł: powołania ogólne/vocat1o general1a/ 1 powołanie speojalne /vocatio specialis/, alo owa antynomie rozwlazal oryginalnie 1 untwersalistycznie. Nie tylko ze Bóg dawaz - 1 daje - wszystkim narodom łaskę ogólna o charakterze nadprzyrodzonym - tyle ze w węzszym zakresie - ale takze obecnie ekonomia spocjalna /vocatio specia11s/ stała sie w jakimś sensie wezystkim wspólna:

"Zadna czéś świata nie jest pozbawiona Ewangelil Chrystusa. A choolaz tamto powolanie ogólne bynajinniej nie ustaje, to przeolez nawet powozanie specjalne stało sie wszystkim irspolne, równiez kazdemu narod ow1 154 .

A zatem jest juź jasno powiedziane przynajmniej, że od czasów Chrystusa kazdy naród objęy jest specjalna ekonomia Boża, która wiedzie go poprzez historie do Chrystusa, do Kościoła Wleków 1 do Królestwa N1eb1esk1ego.

\section{IV.' z prakseologil powozania}

Ostatni punkt uniwersalizacji ekonomil Bozej lezy w problemie praxis ohrześc1jańskiej. Praxis ta z kolel była wówczas osadzona - z chrześojjańskiego punktu widzenla - na płaszczýnie opotkania

53 II,4,690A: "... praesent1a salut1s 1psius ac virtute nihil vacuum fuit".

54 II,33,717C: "Nulla pars mundl ab Evangel1o vaoat Chr1at1. Et lioet 1lla generalis vooatio non quiesoat, tamen etiam ista speclalis lam universis est raota communis. Ex omni gente...". Por. P. de Letter, Gratia generalis in the De vocatione omnium gontium and In St.Augustine, StP 14/1968/393-401. 
s1e Woll Bozej 1 woll ludzk1ej55. Podezas gdy ujecie klasyczne w teolog 11 pod wpływem augustynizmu sprovadzało całokształt rzeczywistośc1 czlowieka 1 narodu do Woll Bozej, poddająo jej takze wiare, sakrament 1 doktrynę, to pelagianizm 1 semipelaglanizm odnosiły to wszystico - z mniej czy bardziej precyzyjnymi rozróznieniami - do wol1 ludzkiej. Stanowisko rzymskie, które niewatpliwie jest reprezentowane w dziełku "De vocatione omnium gentium", opiera $81 \theta$ na misterium "wolnego" zwizzania sig wold ludzkiej z Wola Boza. Podobnie tez zasługa togo dziełka jest próba wiłkszego dowartościowanja czynnika ludzklego w chrześc1jaństivie, bez naruszania wszakze apriorycznogo charakteru czynnika Boskiego:

"Podział na niezalezne od siebie dziazanie ozłowleka /wole/ oraz ekonomie Boza/łaskę/mlałby postaó wiwisekoji; jeśl1 gie usunie wole ludzka, to znika 1 laska"56.

W traktacie "De vocatione omntum gentium" kryje sie myśl, ze włá́nie tajemnica woll ludzklej "dobrej" odgrywa pewna role w przetirarzaniu powołania ogólnego na specjal ne. Ekonomia ogólna pozostaje sferze pozaludzkiej, natomiast ekonomia specjalna staje sie taka z chwilaz, gdy podpada pod instancje woll ludzklej, oczywiścle wtórnej w stosunku do Woll Bozej ${ }^{57}$. Osoba ludzka jest tajemniozym młejscem przekładu ekonomil ogólnej na speojalną. Kaźdy ozłowiek 1 naród moze sprowadzić laske ogólnq na specjalną, jeśl1 nastawi sie do nief responsorycznie. Zapewne w tym znaczeniu II redakcja naszego traktatu podkreśla często, ze nieprzejácle laski ogólnej w speojaIna jest wina tylko woll ludzkiej, nie zas Bozej ${ }^{58}$. Czynnik woll ludzkiej, o lle otwiera sig na Wole Boza, otrzymuje oós owej "sprav1edl1wośc1" lask1, tworzao Jaką́ "równośó" szangy zbawczej dla kazdego człowieka 1 kazdego narodu mimo ogromnego zróznicowania egzystencjalnego /virtute una, indifferenter/59.

65 Por. A.Bober SJ, Antologla patrystyozna, Krakóvi 1965, 274 nn.; Cz.Bartnik, Nadzieje upadajacego Rzymu. Papleska wizja świata ze schyłku 1mpertum rzymskiego, Tarszawa 1982, 103 nn.

56 I, 1,649B. Por. I, 6, 653A; I, 7,653-654.

57 Por. II, 29,715B.

58 II, 10,695C; II, 12,697B; II, 13,698; II, 26,711C; II, 28, 713A.

59 II, 5, 691B; II, $6,691 \mathrm{BC}$; II, 16,703C; II, 25,711A; II, 31,716C. 
Zwiazanie obu czynnikór, Wol1 Bozej 1 wol1 ludzkiej, nie oznacza, oczywiśc1e, 1ch równorzędnośc1. Rozwiazzanie chrześcijatiskie mu81 przyznawać deoydująca role czynnikow1 Bosklemu, odgórnemu, aprioryoznemu, Inaczej ozłowlek owl trzeba by przyzná moc autokreacyjna. Jednakze nawet przy takim stosunku zaleźności wola ludzka nie przestaje byó wolna, a nawet dzięl temu otrzymuje coś z wolnośl partnerstwa: Bóg "przygotowuje plerwsza wolę", ale włá́nte jako "przyjmujaca" Boga 1 jako wolna do przyjęc1a Woll Bozej60. Cała wezo rzeczyw1stość dana człorlekowl 1 narodow z góry, zacznio z zaska nadprzyrodzona, stanowi w konsekwencj1 pewne tworzywo dla dziatania ludzklogo szerokim zakresio: "operis matorian"1. Wola ludzka mozo nio tylko stawlać przeszkody zasce Bozej, co byzo dla ohrześcljan od poczatku oczywiste, ale może takze warunkować dzlakanie kask1 w sposób pozytymy w zakresie stworzenia 1 zbawienia. Po prostu listor nlezbawienia jest nastepstwem moralnych braków osoby ludzkiej, a his.. torla zbarienla jest rspolnym orocem 1 zask 1 Bozej 1 woll ludaklef ${ }^{62}$. Zasada ta jest tak powszechna, ze nawet $n$ przypadku niemowlat, nte uzywajacych swej wol1, lch egzystencje zbawcza warunkuje w pewnej mierze wola Innych ludzi: rodz1oów, najbliżzego otoczenła, Kościo$\mathbf{~}^{63}$. Przy tym ekonomia Boza jest jakoś uwarunkowana po częśc1 nawet zdolnośc1am1 recepcyjnym1 1 responsorycznym1 konkretnej nol1: "secundum propriam ot naturalem possibilitatem "..."secundum modulum capac1tat1s suae" 64 . Jest to więc zasada synergizmu bosko-ludzkiego na wzór Chrystusa. Szczególnie ksiegga II ksztaituje 1dee człowleka 1 narodu jako podmlotu ekonomil Bozej, Jako rozumnego 1 wolnego jej mspózpracownika: /cooperator, adiutor, exercens, studens, operarius, minister/65. Ta cooperatio stanowi niejako ową "druga wolę", która nie jest zdeterminowana z góry bez reszty. Dazzenie do

60 II,26,712A: "... primam s1b1 receptrioem et famulam donorum suorum praeparat voluntatem". Por. II, 27,712CD.

61 II, 8, 693B.

62 II,26,711C: "... et quod /gratia ohristiana/ a multis refutatur, ipsorum est nequitiae: quod autem a multis suscipitur, et gratlae est divinae et voluntatis humanae".

63 II, 20,707B; II, 23,709D; II, 26,711B.

64 II, 8,693AB; II, 24,710BC.

65 II, 6,691D; II, 12,697B; II, 26,711C; II, 27,712BCD; II, 35,720A. 
mspołpracy z czynnikiem Boskim jest nie tylko dopuszczalne, ale nawet nakazane pod kara potepienia ${ }^{66}$. Koronuje te myśl zdanie ep1logu, ze mimo wykroczén ze strony człowleka "stało sie dobrze, iz wola jest molna"67.

7 rezultacie ludzie 1 narody maja pewien udziaz w tworzeniu wlasnej histor11. Wprawdz1e Bóg jest wolny w swolch planach h1storyoznych, które nle moga byó determinowane przez czlowieka, to jodnak Opatrzność układa te plany po czéćc1 aposterlorycznlo, to znaczy takzo stosornie do tego, Jakie sa ostateczne rezultaty dziez ludzkich 1 jaka okaze sie rola człowleka68. Dzlałania ludzkie zatem, "przód przeridziane, mystępuja Dlatego porołanie chrześctjańskie staje s1e rónoznaczne z powołaniem do praxis chrześcijańskiej, do działanla, ozynu. Z racj1 mięc osojowego charakteru Boga jako ostatocznej przyczyny dziejów wierzymy goraco, te wszystkie nasze dzlałania, a takze wszystk1e owe zróznicowania egzystencjalne maji pewien wpływ na nasze losy. F mýl tego człowiek staje sig odpowiedzialny za rozwóf swego ducha, moralnośc1, kultury, zasług, modl1twy, religljnośc1, samego Koścloła, a nawet rszystkie przecirnoścl przyczyniaji sle do powstanla dynamik1 egzystencjalnej, konlecznej dla rozwoju jednostek 1 narodów ${ }^{69}$.

Najgłębsze odpowledzl dzlełka "De vocatione omnlum gentium" na problem powołania narodór maja chara'ster nie tyle misterium bytu, co raczej nisterlum dzlakania 1 poralnośc1. Dlatego głónna role w Interpretact1 historil odgrysaja wartosc1, przede wszystkim moralne. Egzystencja ludzka jest zawieszona mifdzy dobrem a złom. Bóg nie tylko nio chce wybawié człowleka z tej ambiwalencji, alo cbce go przeprowadzić przez sam jej środek. I czkowiek musi wzląó w tym świadomy 1 wolny udzlał. Stąd czyny najbardzlej htstoryczne to czyny moralne. Uistoria ludzka jest określona przez moralność. Sama teorla predestynacjonizmu na Zachodzie wywodziła sie z przekonania - prymacie wartośct moralnych w losie człowleka. Tym bardziej powozanie 1 wybór jednostek 1 narodów zakłada konleczność ich dzlałania:

66 II, 8,693C: "... neo do non servato, sed de non aucto munere dampabuntur". Por. II, 8,693ABC.

67 II, 34, 719C.

68 II, 24,710B; II, 29,715BC; II, 34,719ABC.

69 II $8,693 \mathrm{BC}$; II $, 10,695 \mathrm{~B}$; II, 23,709C; II, 26,711CD-712A; II, 33, $717 \mathrm{CD}-718 \mathrm{~A}$; II, 34,719BC; II, 36,722A; II, 37, 722AB. 
"Bo błednle mów1 s1e, te wybrani nie maja raojl, teby dzlaład, gdyz waśnte sa onl wybrant po to, zeby dzlałaco70. W czynie, dla którego norma jest laska ohrześc1janska, jest w1ele z samorealizacj1. Rórnlez czyny narodó sa konlecznym elementem realizacjl Boźej ekonomil of ślec1e.

\section{K8. Czesłan Bartn1k - Lubl1n}

\section{ÜBER DIE BERUFUNG DER NATIONEN ZU CHRISTUS /Zusammeneassung/}

Im Artikel wird detallilert aufgezelgt, wie das wahrschein$11 \mathrm{ch}$ in den Jahren 460-468 in Rom entstandene patristischo Werk "De vocatione omnlum gent1um" elne bestimme Theologie der Gesohichte nicht nur des Individuums, sondern auch der Nation beinhaltet. Je mohr stch dieses klelno Werk dem Ende nuhert, umso deutlicher wird der Universal1smus der Berufung jeder Nation dor Volt, ohne Rackslcht auf die Zo1t, zur christichen Gnade, zu Ciristus und zu dor elnen Kirche erkennbar. Die Berufung der Nation nimnt in der Geschichto dor Menschholt vielfultige Formen an, abor jede Nation strebt nach dem Relch Christ1, auch wenn wir das manchmi nioht sohon konen. Dile generelle Berufung der Nation wird durch ef.

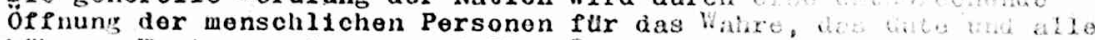

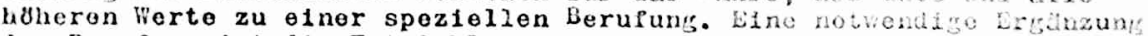

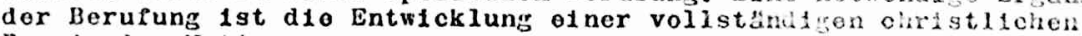
Praxis der Nation.

70 I $1,35,720 B$ : "Bit erustra dicitur quod ratio operandi non sit in electis, cum etiam ad hoc ut operentur olocti sint". 